Karstenia 46: 17-24, 2006

\title{
Variability of Hydnum rufescens in Finland: three taxa hidden under one name - and appearance?
}

\author{
SEPPO HUHTINEN and JUHANI RUOTSALAINEN
}

\begin{abstract}
HUHTINEN, S. \& RUOTSALAINEN, J. 2006: Variability of Hydnum rufescens in Finland: three taxa hidden under one name - and appearance? - Karstenia 46: 17-24. Helsinki. ISSN 0453-3402.

Recent observations revealed large variability in spores between materials collected as Hydnum rufescens Fr. New collections and herbarium specimens indicated that Finnish material can be divided into three entities based on spore characters. One of these, with ellipsoidal spores, was described as new by other workers. This species, Hydnum ellipsosporum Ostrow \& Beenken, is not rare in Finland. In Finnish populations of $H$. rufescens s.str. spores are typically globose. Populations with intermixed broadly elliptical spores are more rare. Spore size in $H$. rufescens is clearly smaller than in H. umbilicatum Peck, in which spores are uniformly globose. A study of the holotype showed spore characters identical to the Finnish material. Hence, H. umbilicatum is claimed to be part of typical European mycoflora; it seems to be fairly common in Finland. Observations made so far indicate that macromorphology and colours may be too variable for a definitive identification in the field. Some possibly helpful, mainly hymenial, characters are discussed. Two collections of $H$. rufescens are reported from Canada. Colour photographs of all the discussed taxa are provided.
\end{abstract}

Key words: Basidiomycota, Hydnum, taxonomy

Seppo Huhtinen, Herbarium, University of Turku, FI-20014 Turku, Finland

Juhani Ruotsalainen, Metsätie 12 A4, FI-71310 Vehmersalmi, Finland

\section{Introduction}

In Finland both Hydnum repandum L. : Fr. and H. rufescens Schaeff. : Fr. are very common and fruit abundantly. For the most part the differences between these two species are clear even though they can occur in similar habitats. However, every now and then macromorphologically intermediate fruit-bodies can be found. Similar observations were reported by, e.g., Otto (1997), who studied a few hundred German collections of these taxa. Such observations led Ostrow and Beenken (2004) to start a molecular study, during which they could confirm the species status of these two taxa. Based on spore characters they explained, to some extent, the variability of $H$. rufescens. Independently, keen Finnish amateur mycologists recently collected specimens of $H$. rufescens with deviating spores. These differ- ences turned out to be clear enough to merit a new species. However, in the midst of such considerations, the study by Ostrow and Beenken (2004) resulted in the description of a new species, Hydnum ellipsosporum Ostrow \& Beenken. Some of the Finnish collections could be referred to this species, however, not all of them. In the collections closest to $H$. rufescens there were two clear sporal entities. A great majority of the studied populations, with wide geographical range, could be classified in two clusters which showed only moderate overlap. These two clusters match the traditional concepts of European $H$. rufescens and American $H$. umbilicatum Peck. The results discussed below will hopefully stimulate future field observations and molecular studies. 


\section{Methods}

The number of spores measured from each population for Figs. 1-2 and for the overall measures in diagnoses varied from 20 to 30 or 60 . Part of the material was determined with fewer measurements and was not included in the above mentioned figures or measures. All measurements were made in lactic acid and at random. When spores from spines were measured, only those with firm walls and uniform contents (in lactic acid) were considered. These were found to be less variable than the badly reviving, thin-walled and often angular spores usually forming a clear majority of spores in a mount.

For each taxon, spores were measured from a spore print of at least one population. All drawings were made in Melzer's Reagent with a drawing tube. All spore sizes, numerical or illustrated include $90 \%$ of the total variability. Occasional extreme values, being part of the excluded $10 \%$, are indicated in parentheses.

\section{Finnish material}

Based on Finnish material, we suggest that the following microscopically recognizable taxa exist: 1) the non-variable Hydnum umbilicatum with large and \pm globose spores, 2) the non-variable, ellipsoid and large-spored H. ellipsosporum, and 3 ) the variable $H$. rufescens typically with \pm globose and small spores but also including populations with more elongate, but still clearly narrower/smaller spores than in the two other taxa. The microscopical features of these three taxa are discussed more thoroughly below. We are unable to give definitive macroscopical, ecological or other microscopical features to separate them. For instance, populations with umbilicate, light-coloured fruit-bodies were found in all three species. Features, which may have some significance, are the frequently darker, longer and thicker spines in H. ellipsosporum. The colour difference between $H$. umbilicatum and $H$. ellipsosporum, seen in Figs. 3 and 6 is also evident in spore prints, whereas $H$. umbilicatum and $H$. rufescens seem to have similar spore colour. The stipe base in $H$. ellipsosporum is mostly equal or slightly tapering, whereas $H$. rufescens often seems to have a somewhat clavate stipe. In some populations of $H$. umbilicatum spine apices are prominently brush-like. Ostrow and Beenken (2004) were also unable to give any definite morphological differences between $H$. rufescens s. 1 . and their new species. As they clearly treated $H$. rufescens more widely than here, by including $H$. umbilicatum, the complexity of the situation in the field may be similar in Central Europe.

In Fig. 1 the spore variability of 22 populations is indicated. As can be seen the new species

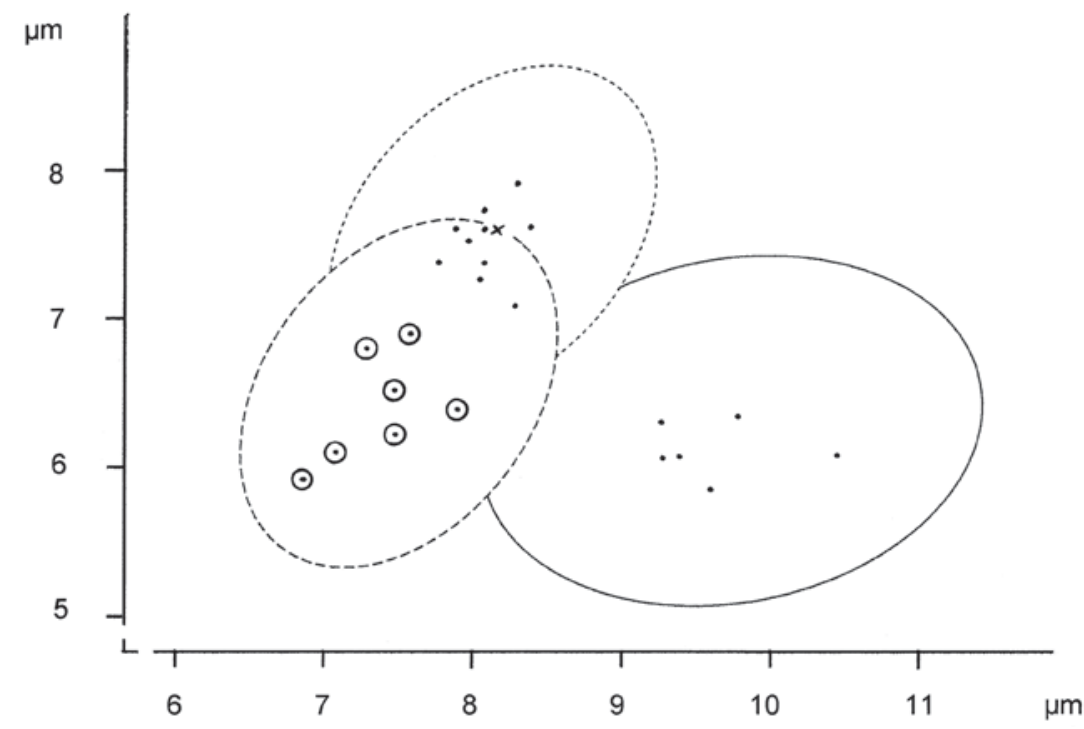

Fig. 1. Spore variability and populational means representing a great majority of Finnish herbarium material collected as Hydnum rufescens. Broken line $=H$. rufescens s.str.; dotted line $=H$. umbilicatum; solid line $=H$. ellipsosporum. $\mathbf{x}$ = type of $H$. umbilicatum. 


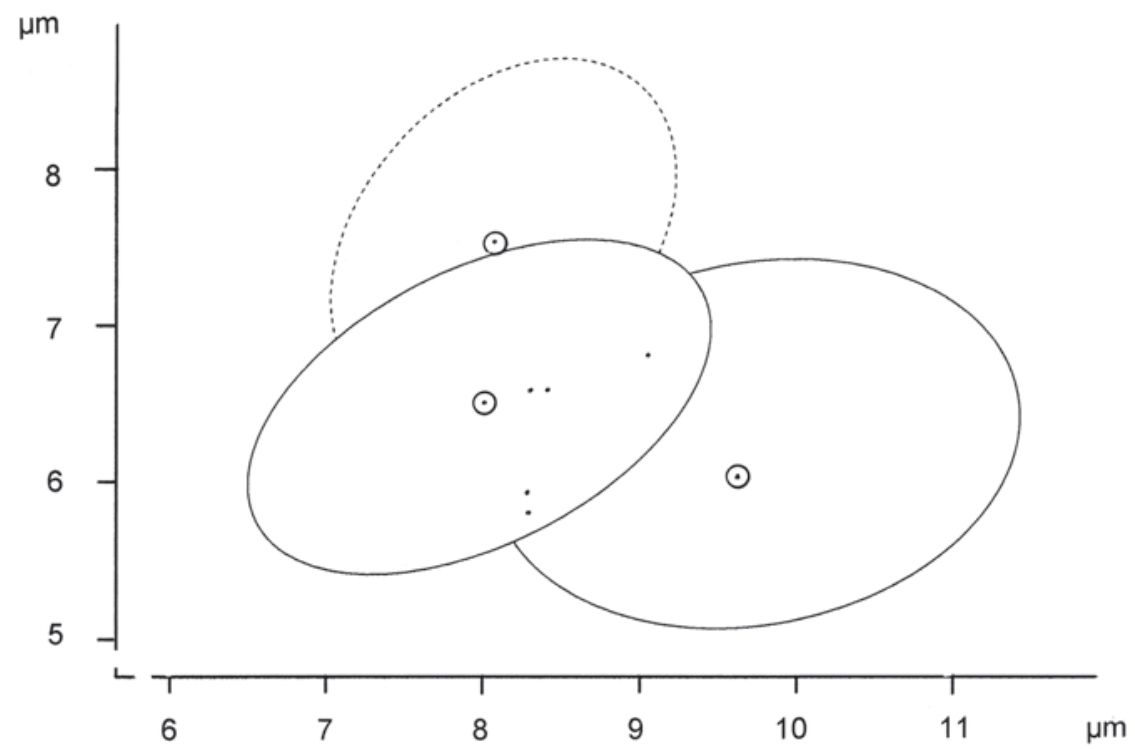

Fig. 2. Spore variability and mean spore size for three species of Hydnum, after the five deviating populations (populational means indicated as dots) are included in H. rufescens.

clearly differs from the rest of the Hydnum rufescens complex. H. umbilicatum and $H$. rufescens s. str. show equal variability in spore characters, with the sole difference of spore size. A great majority of Finnish material follows this pattern. During the study five problematic specimens were also encountered, which did not follow the pattern. Even when mounted from a spore print, their spores were often somewhat elongated, hence varying towards $H$. ellipsopsorum. But the spore dimensions were notably smaller than in $H$. ellipsopsorum and did not show marked overlap. Allowing such populations into the variability of $H$. rufescens did not blur the three entities of "normal" collections. These populations changed the direction of variability somewhat more towards $H$. ellipsosporum, but total means are still prominently different (Fig. 2). Using DNA analysis Ostrow and Beenken (2004) showed that $H$. rufescens and $H$. ellipsosporum are sister species. From their spore measurements it is evident, however, that the sole analyzed collection under the name $H$. rufescens (LB804) concurs with the material here called $H$. umbilicatum. Molecular work and numerous observations of fresh specimens seem to be the only way to solve the problem.

\section{Hydnum umbilicatum and $\boldsymbol{H}$. rufescens} - Figs. 3-6

For a long time these two names have been used uncritically. European material with plano-convex to depressed pileus bears Fries' name. Umbilicate pilei have been considered as just part of normal variability. H. rufescens has been reported to have small spores, but was also allowed to show a wide variability in spore size (e.g. Maas Geesteranus 1975, Pegler et al. 1997). American specimens were referred to $H$. umbilicatum with the stress on the umbilicate to depressed pileus and large spores (e.g. Hall \& Stuntz 1971). New ideas arose in the 70's and 80's. Maas Geesteranus (1976) commented on two specimens collected in Sweden by M. \& J. Jeppson. However, Maas Geesteranus did not report Peck's species as new to Europe, due to the pale colours of the fruit-bodies. Ryman and Holmåsen (1984), referring to the same material also, indicated the possibility of $H$. umbilicatum being part of Swedish mycoflora. Maas Geesteranus (1976) stressed the need for a larger study of material from both continents and the matter has remained more or less open. Harrison and Grund (1987a, 1987b) confirmed that H. rufescens also 

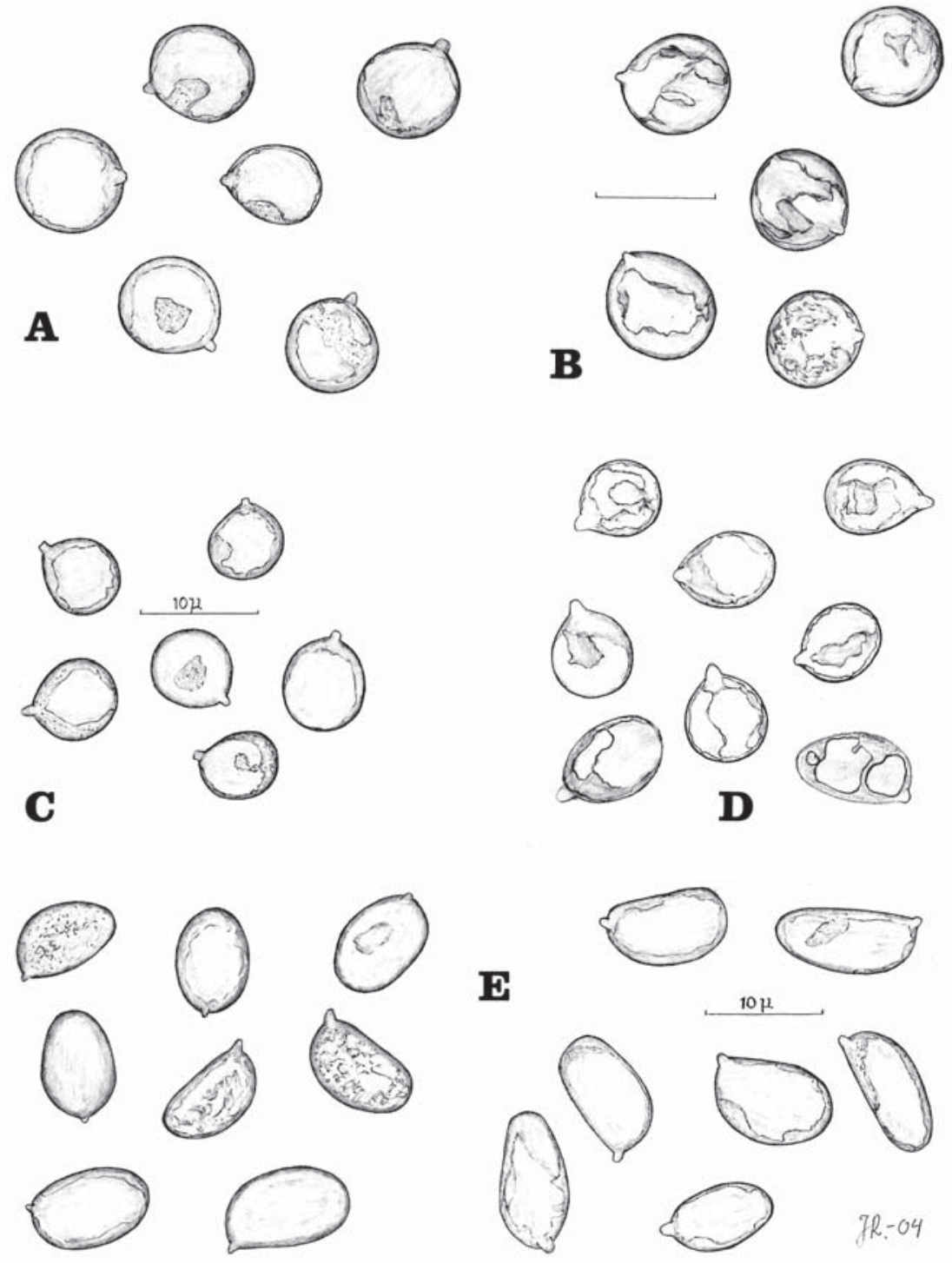

Fig. 3. Spores from the Hydnum rufescens complex. - A) H. umbilicatum, Ruotsalainen 6867. - B) H. umbilicatum, type. - C) H. rufescens, common spore type, Ruotsalainen 6715. - D) H. rufescens, rare spore type, Ruotsalainen 6881. - E) H. ellipsosporum, Ruotsalainen 6556F. Scale bars $10 \mu \mathrm{m}$.

occurs in North America. Material from Québec is also presented in the present study. Recently Lüderitz (2005) briefly reported $H$. umbilicatum from Sweden and Germany; the article includes a colour photograph of a pale, umbilicate Hydnum but no microscopic data. Almost all authors have reported on the difficulty of judging colour variability, whereas "anomalies" in pileus shape have not been discussed.
Spore measurements in the Finnish material of Hydnum umbilicatum match perfectly those in Peck's type specimen (Fig. 1). The mean in the Finnish material was $8.1 \times 7.5 \mu \mathrm{m}(\mathrm{n}=260$ from 10 populations). In the type, the mean was 8.2 $\times 7.6 \mu \mathrm{m}(\mathrm{n}=30)$, and the spore quotient varied between 1.0 and 1.2 with a mean of 1.0. In Finnish material the range was $1.0-1.3$ and the mean $1.0(n=260,10$ populations $)$. The size range in 
Finnish material was $7.4-9.0(-9.8) \times 6.5-8.3$ $(-8.8) \mu \mathrm{m}$. In the type specimen it was almost identical: $7.4-9.0 \times 7.0-8.7 \mu \mathrm{m}$. In the type specimen a great majority of spores were poorly reviving and those illustrated in Fig. 7B represented a small minority.

The spores of $H$. rufescens are smaller than in H. umbilicatum. The typical Finnish specimens show the following mean measurements: $7.4 \times$ $6.5 \mu \mathrm{m}$ ( $\mathrm{n}=220$, from 8 populations), $\overline{\mathrm{Q}}=1.2$. Spore size range was $6.4-8.2(-9.0) \times 5.8-7.2$ $(-8.4) \mu \mathrm{m}$ and the Q-index $1.0-1.3(-1.4)$.

The somewhat deviating specimens showed a mean of $8.5 \times 6.3 \mu \mathrm{m}(\mathrm{n}=120$, from 4 populations). These collections had longer spores than typical $H$. rufescens with $\overline{\mathrm{Q}}=1.4$; range $1.1-1.7$ $(-1.8)$. Their variability in shape marks a clear difference compared with $H$. umbilicatum, in which spore variability is small and all population means are tightly clustered (Fig. 1). The solution offered here is that these populations are best placed in H. rufescens, where they do not dramatically change the whole variability of the species. We definitely need more information of this deviating spore type to decide whether a fourth taxon is "hidden" in the total variability of Hydnum rufescens s.lat.

\section{Hydnum ellipsosporum - Figs. 3, 7}

The thorough description of this species by Ostrow and Beenken (2004) fits Finnish material very well. The type specimen has the following spore size: $8.5-11.0 \times 5.5-7.5 \mu \mathrm{m}, \overline{\mathrm{x}}=10.0 \times$ $6.6 \mu \mathrm{m}, \mathrm{Q}=1.3-1.8, \overline{\mathrm{Q}}=1.5$ (in $\mathrm{KOH}, \mathrm{n}=100)$. The total spore variability was given as: 9.0 - $11.0(-12.0) \times 6.0-7.5 \mu \mathrm{m}$ (mean not indicated, $\mathrm{n}$ apparently 400 , from four populations). Finnish material was measured in lactic acid which revived the spores more tardily than $\mathrm{KOH}$, or ammoniacal Congo red. Measurements were conducted at random as was done by Ostrow and Beenken. The mean in our material is a bit smaller: $9.6 \times 6.0 \mu \mathrm{m}(\mathrm{n}=230,8$ populations $)$. The spore quotient varies between 1.3 and 1.8 , $\overline{\mathrm{Q}}=1.6$. The total variability is as follows: 8.7 $-11.0(-12.0) \times 5.2-7.0(-7.8) \mu \mathrm{m}(\mathrm{n}=230$, 8 populations). Also comparison between Fig. 1 and the spore diagram from the type specimen (Ostrow \& Beenken 2004: 150) shows an almost total match.

\section{Ecology \& phenology}

The studied populations cover a relatively large geographical area, up to ca. $1000 \mathrm{~km}$ apart. They all seem to have a wide ecological amplitude. Hydnum rufescens has been collected from, e.g., the following habitats: a Tilia plantation, rich Quercus forest, old and mossy spruce forest, herb-rich spruce forest, amongst Sphagnum in paludified spruce forest, and on a lime-rich rocky outcrop. H. umbilicatum collections originate, e.g., from following sites: herb-rich spruce forest, pine-dominated forest, amongst Sphagnum with spruces and birches nearby, a margin of a rich mire, birch forest, spruce forest, moist shore forest with alder and spruce, Quercus-Corylus forest and spruce forest on lime-rich soil. Lüderitz (2005) stated the species to be a good indicator species for Carpinion betuli -type forests. H. ellipsosporum shows the following ecological amplitude: pine heath, old spruce forest, moss-rich coniferous forest, Quercus-Corylus forest, grassy forest margin with pines and birches, herb-rich spruce forest and rich forest with spruce and Corylus. The widest ecological amplitude is that of $H$. rufescens, which has also been shown to grow in alpine region, possibly in connection with Betula nana. The only other marked difference is that $H$. ellipsosporum has not yet been collected from paludified sites. This is also the case in the large material cited by Ostrow and Beenken (2004). It seems to be almost impossible to use ecology as a definite aid in the field.

In Finland, both H. rufescens and H. umbilicatum fruit from mid July to the fall of snow in November or December. The fruiting season of $H$. ellipsosporum starts in early September and extends to the fall of snow. This might suggest that it is not as early a species as the other two. The large quantity of material treated by Ostrow and Beenken (2004) indicated fruit-body production from August to December. More observations are needed to see if there are any true differences in phenology between $H$. ellipsosporum and the other two.

\section{Material studied}

Hydnum rufescens. (47, specimens marked with asterisk also show somewhat deviating, more elongate spores). FINLAND. Ahvenanmaa. Jomala, Moren, 9.IX.1992 Vauras $7315 F$ (TUR-A). - Varsinais-Suomi. Halikko, Vaisakko, 6.X.2004 Heinonen \& Heinonen 824-2004 


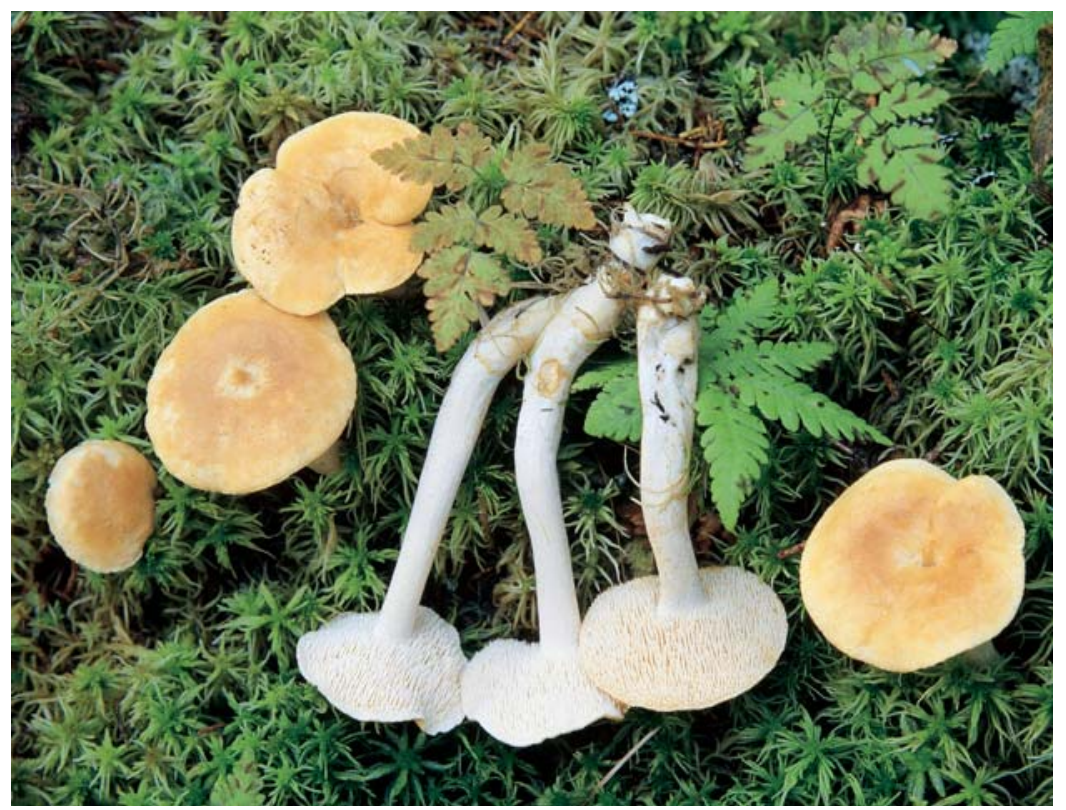

Fig. 4. Hydnum umbilicatum, Niemelä 7612, Kinnunen \& Schigel. Photo: T. Niemelä.

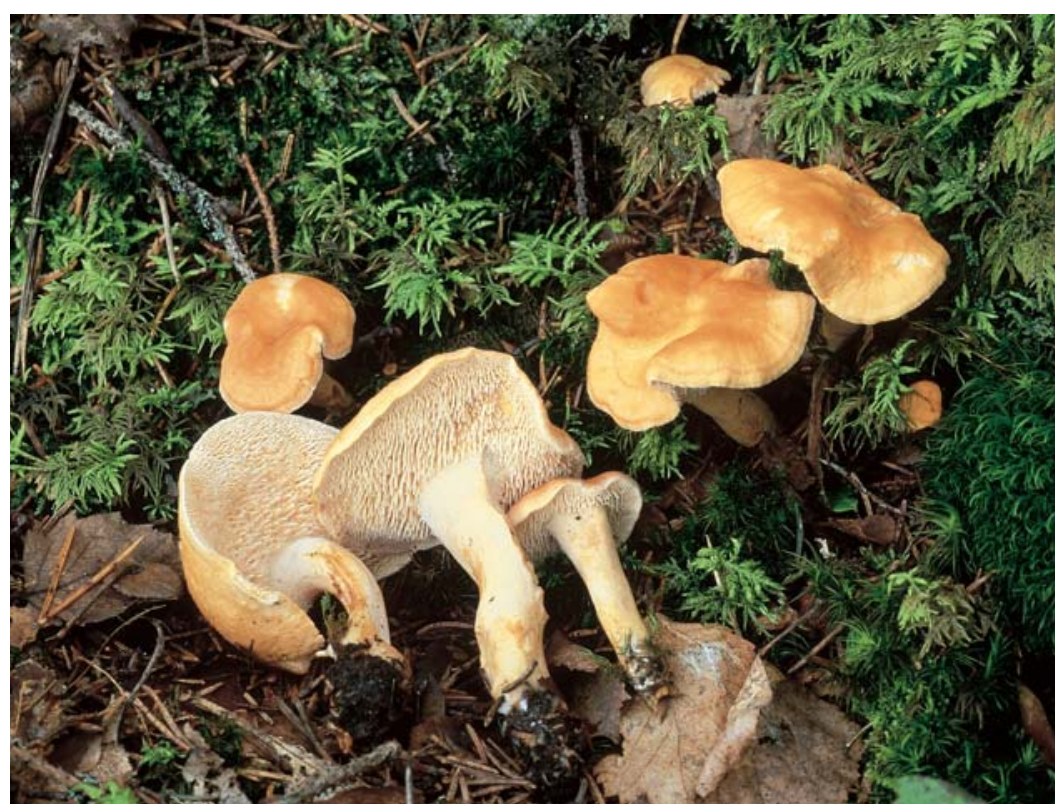

Fig. 5. Hydnum umbilicatum, Heinonen \& Heinonen 838-2000F. Photo: P. Heinonen.

(TUR). Kaarina, Kuusisto, 11.IX.2000 Heinonen \& Heinonen 1096-2000 (TUR). Kuusisto, 30.XI.2000 Heinonen \& Heinonen 1470-2000* (TUR). Paimio, Huso, 9.XI.1972 Alava \& Alho (TUR). Paimio, Kurki, 7.XI.1971 Alho (TUR). Parainen, Lillmälö 6.VIII.1974 Alho (TUR). Tammisaari, Tenhola, 11.VIII.2000 Vauras $16471 F$ (TUR-A). Tammisaari, Bromarv, 5.VIII.2000
Korhonen 12945 (TUR). Turku, Ruissalo, 10.XI.2004 Huhtinen 04/141* (TUR). - Uusimaa. Porvoo, Stensböle, 30.VIII.2004 Salo \& Salo 9798 (H). - Etelä-Karjala. Miehikkälä, Pekkola, 26.IX.1970 Fagerström (H). - Satakunta.Viljakkala, Inkula, 10.IX.2000 Niemelä 6877 (H). - Etelä-Häme. Asikkala, Vääksy, 3.IX.1984 Kytövuori 84340 (H). Korpilahti, Vaarunvuoret, 13.X.1975 E. Ohe- 


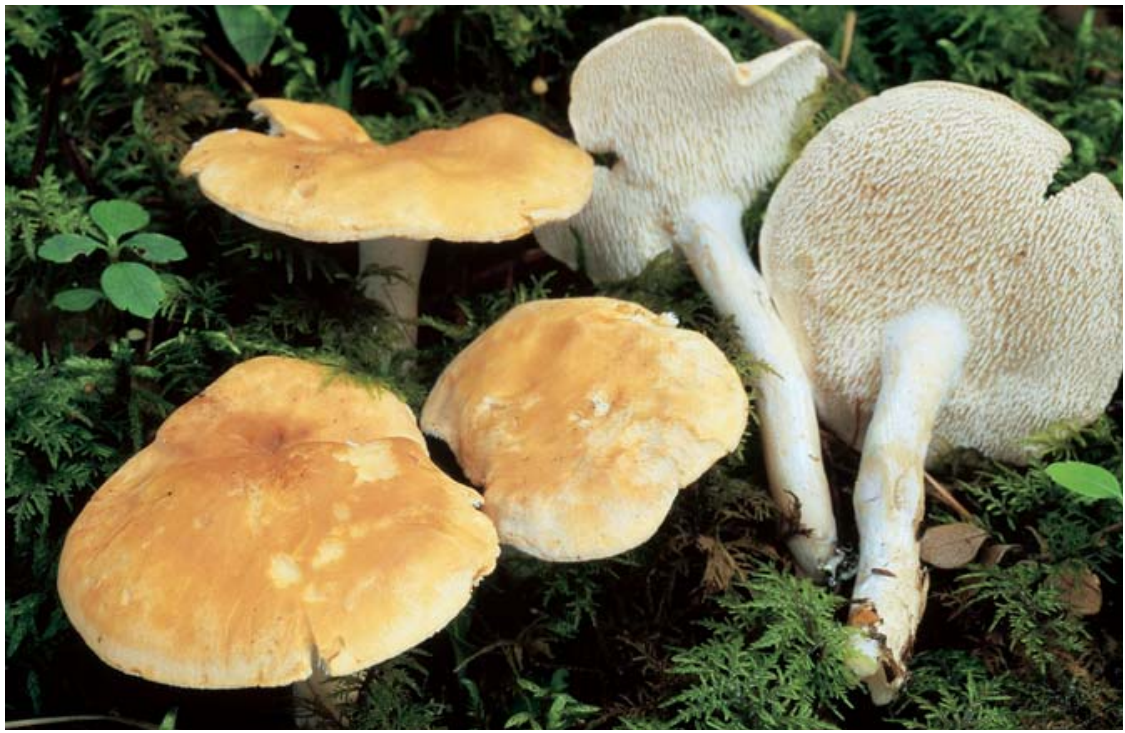

Fig. 6. Hydnum rufescens, Ruotsalainen 6715F. Photo: J. Ruotsalainen.

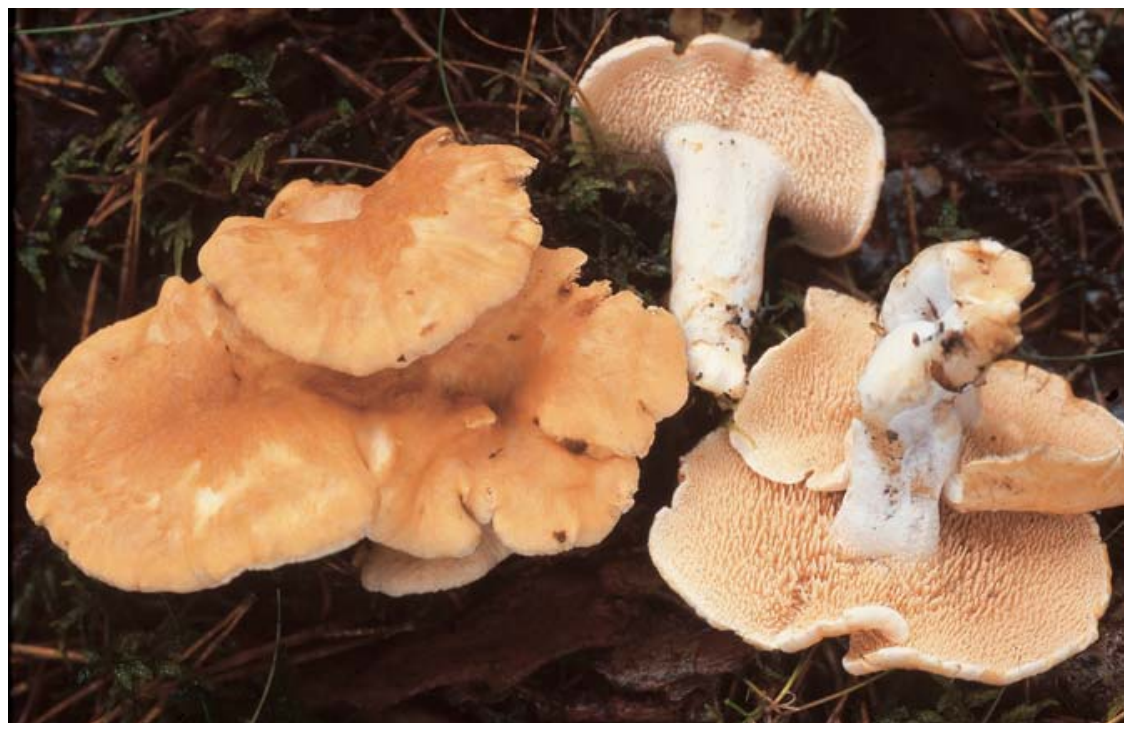

Fig. 7. Hydnum ellipsosporum, Ruotsalainen 6556F. Photo: J. Ruotsalainen.

noja (OULU). Lammi, Pappila, 3.IX.1973 Fagersten \& Haapasaari (KUO). - Etelä-Savo. Rantasalmi, Linnasaari, 18.VIII.1979 Oinonen (KUO). - Pohjois-Savo. Kuopio, Puijo, 27.X.2004 Ruotsalainen $6887 *$ (KUO, TUR). Puijo, 27.X.2004 Ruotsalainen 6889*(KUO, TUR). Kuopio, Matkusjärvi, 27.X.2004 Ruotsalainen 6881* (KUO, TUR). Kuopio, Vehmersalmi, Räsälä, 2.X.2004 Ruotsalainen $6703 F$ (KUO), $6872 F$ (KUO, TUR). Vehmersalmi, Puutosmäki, 26.VIII.1973 Hakala (KUO). Kuopio, Hiltulanlahti, 16.VIII.1974 Fagersten 2504 (KUO).
Hiltulanlahti, 8.X.1974 Heikkilä 565 (KUO). Nilsiä, Kinahmi, 20.VIII.1981 Takala 13177 (KUO). Siilinjärvi, Kehvo, 18.VIII.1983 Takala 13870 (KUO). Suonenjoki, 10.X.2003 Eskelinen (KUO). Tuusniemi, Hiidenlahti, 1.X.1975 Heikkilä 75-309 (KUO). - Pohjois-Karjala. Joensuu, Linnunlahti, 9.VIII.1979 Heikkilä 79-430 (KUO). Juankoski, Säyneinen, 1.X.2004 Ruotsalainen 6715F (KUO, TUR). - Keski-Pohjanmaa. Haapajärvi, Varisperä, 22.VII.1970 E. Ohenoja (OULU). Reisjärvi, Jäppiperä, 25.VII.2000 E. Ohenoja (OULU). - Kainuu. Puolanka, 
Joukokylä, 30.VIII.1998 E. Ohenoja (OULU). - Kuusamo. Posio, Riisitunturi, 9.VIII.1979 Eurola (OULU). Oulun Pohjanmaa. Kuivaniemi, Kalkkimaa, 23.VII.1984 E. Ohenoja (OULU). - Perä-Pohjanmaa. Keminmaa, Kallinkangas, 20.IX.1987 Tammilehto (OULU). Kiiminki, Juuansydänmaa, 2.VIII.1966 Ulvinen (OULU). Pudasjärvi, Siivikko, 23.VII.1975 E. Ohenoja (OULU). Rovaniemi, Pahtaja, 15.IX.1988 E. Ohenoja (OULU). Tervola. Sihtuuna, 20.IX.1998 E. Ohenoja (OULU). Ylikiiminki, Jokikokko-Ylivuotto, 11.VIII.1966 M. Ohenoja (OULU). - Enontekiön Lappi. Kilpisjärvi, Saana, 18.IX.1985 Virolainen (OULU). Saana, 13.VIII.1981 Metsänheimo (OULU). Saana, 19.VIII.1981 Metsänheimo (OULU). Saana, 24.IX.1966 Ulvinen (OULU). - Inarin Lappi. Utsjoki, Ailigas, 20.VIII.1966 Suominen (TUR). CANADA. Québec, Schefferville, 14.VIII.1979 Huhtinen \& Kosonen (TUR); 27.VIII.1979 Huhtinen \& Kosonen (TUR).

Hydnum umbilicatum. (24) FINLAND. Varsinais-Suomi. Nummi-Pusula, Heijala, 6.IX.1970 Uotila 6209 (H). Parainen, Prästgården, 17.XII.2000 Heinonen \& Heinonen 1538-2000 (TUR). Perniö, Joutna, 14.VIII.1991 Vauras 5757 (TUR-A). - Uusimaa. Porvoo, Bjurböle, 25.VIII.1998 Nummela-Salo \& Salo 5503 (H). - Etelä-Karjala. Imatra, Karhusuo, 10.VIII.1987 Kytövuori 87189 (H). - Satakunta. Lappi, Lapinkylä, 2.X.1957 Såltin (OULU). - Etelä-Häme. Vilppula, Elämänmäki, 22.VIII.2004 Ruotsalainen 6659 (TUR). Tammela, Syrjä, 14.VIII.2000 2004 Heinonen \& Heinonen 838-2000F (TUR). - Etelä-Savo. Joutseno, Ahola, 12.VIII.1987 Kytövuori 87335 (H). - Pohjois-Häme. Laukaa, Iso-Harinen, 10.IX.2004 Ruotsalainen 6765 (TUR). - EteläPohjanmaa. Laihia, Peltomaa, 11.IX.1979 Kiviluoma (OULU). - Pohjois-Savo. Kuopio, Vehmersalmi, Miettilä 2.X.2004 Ruotsalainen 6867F (KUO). - Pohjois-Karjala. Värtsilä, Savikko, 3.IX.1993 Väre (OULU). - KeskiPohjanmaa. Pyhäjärvi, Vuohtomäki, 19.VII.1983 E. Ohenoja (OULU). - Kainuu. Paltamo, Melalahti, 22.IX.1983 Ulvinen (OULU). Sotkamo, Haapanlahti, 25.VIII.1972 Kaakinen (OULU). - Perä-Pohjanmaa. Haukipudas, Martimo, 4.IX.1966 M. Ohenoja (OULU). Keminmaa, Kallinkangas, 13.XI.1982 Tammilehto (OULU). Kuivaniemi, Tuulijärvi, 8.VIII.1976 Hakulinen (OULU). Tervola, Pahtaoja, 9.X.1997 E. Ohenoja (OULU). - Perä-Pohjanmaa. Rovaniemi, Pisavaara, 31.VIII.2003 Niemelä 7612 et al. (H). - Kuusamo. Hiltunen, Iivaara, 31.VIII.1977 Ulvinen (OULU). - Sompion Lappi. Pelkosenniemi, Ahvenaapa, 29.VIII.1994 Nummela-Salo \& Salo (OULU). - Enontekiön Lappi. Enontekiö, Kilpisjärvi, 18.IX.1985 Virolainen (H). U.S.A. New York. Adirondack Mountains, Hague, Hoodwood, Peck (NYS, holotype).

Hydnum ellipsosporum. (18) FINLAND. VarsinaisSuomi. Dragsfjärd, Dalsbruk, 8.X.1972 Federley (H). Halikko, Vaisakko, 1.XI.2004 Heinonen \& Heinonen
1042 -2004 (TUR). Koski T1., Värmelä, 25.IX.2000 Heinonen \& Heinonen 1215-2000F (TUR). Parainen, Kirjala, 29.IX.2000 Heinonen \& Heinonen 1223-2000F (TUR). Pohja, Skuru, 30.X.1965 Såltin (OULU). Pöytyä, Karinainen, Karvionkulma, 7.XI.2004 Huhtinen 04/130 (TUR). Turku, Ruissalo, 10.XI.2004 Huhtinen 04/140 (TUR). - Etelä-Häme. Hämeenlinna, Hattelmalanharju, 19.X.1974 E. Ohenoja (OULU). Iitti, Haapa-Kimola, 14.X.1984 Haikonen 5107 (H). Jokioinen, Rehtijärvi, 20.X.1974 E. Ohenoja (OULU). - Pohjois-Savo. Leppävirta, Tuppurinmäki, 9.XI.2004 Ruotsalainen 6892 (KUO, TUR). Kuopio, Hiltulanlahti, 8.X.2005 Ruotsalainen 7168 (KUO, TUR). Kuopio, Vehmersalmi, Ritoniemi, 1.X.2004 Ruotsalainen 6875 (KUO). Ritoniemi, 16.X.2004 Ruotsalainen 6877 (KUO). Vehmersalmi, Roikansaari, 12.X.2003 Ruotsalainen 6868F, 6556F (KUO). Vehmersalmi, Jänissalo, 10.X.2005 Ruotsalainen 7174 (KUO, TUR). Nilsiä, Kalkkiruukki, 9.X.2003 Ruotsalainen 6555 (KUO). - Kainuu. Hyrynsalmi, Paljakka, 11.IX.1976 Lindgren (OULU).

\section{References}

Hall, D. \& Stuntz, D.E. 1971: Pileate Hydnaceae of the Puget Sound area. 1. White-spored genera: Auriscalpium, Hericium, Dentinum and Phellodon. - Mycologia 63: 1099-1128.

Harrison, K.A. \& Grund, D.W. 1987a: Preliminary keys to the terrestrial stipitate Hydnums of North America. - Mycotaxon 28: 419-426.

Harrison, K.A. \& Grund, D.W. 1987b: Differences in European and North American stipitate Hydnums. - Mycotaxon 28: 427-435.

Lüderitz, M. 2005: Svampar I Natura 2000-områden - ett project för identifiering och indikering av naturtyper. - Sv. Mykol. Tidskr. 26: 90-95.

Maas Geesteranus, R.A. 1976: Notes on Hydnums. 10. - Koninkl. Nederl. Akademie van Wetenschappen, Proceedings C 79: 273-289.

Ostrow, H. \& Beenken, L. 2004: Hydnum ellipsosporum spec. nov. (Basidiomycetes, Cantharellales) - ein Doppelgänger von Hydnum rufescens Fr. - Z. Mykol. 70: $137-156$.

Otto, P. 1997: Kommentierter Bestimmungsschlüssel der terrestrischen Stachelpilze Deutschlands mit taxonomischen und nomenklatorischen Anmerkungen. - Boletus 21: 1-21.

Pegler, D.N., Roberts, P.J. \& Spooner, B.M. 1997: British chanterelles and tooth-fungi. An account of the British cantharelloid and stipitate hydnoid fungi. $-114 \mathrm{pp}$. Royal Botanic Gardens, Kew.

Ryman, S. \& Holmåsen, I. 1984: Svampar. En fälthandbok. -718 pp. Interpublishing, Stockholm. 